\title{
Communication
}

\section{First Report on Natural Infection of Nodavirus in an Echinodermata, Sea Cucumber (Apostichopus japonicas)}

\author{
Chong Wang ${ }^{1,2}$, Liang Yao ${ }^{2}$, Wei Wang ${ }^{2}$, Songwen Sang ${ }^{2}$, Jingwei Hao ${ }^{2}$, Chenghua Li ${ }^{1, *}$ and Qingli Zhang ${ }^{1,2, *}$ \\ 1 School of Marine Sciences, Ningbo University, Ningbo 315311, China; wangchongyilin@163.com \\ 2 Yellow Sea Fisheries Research Institute, Chinese Academy of Fishery Sciences, Function Laboratory for \\ Marine Fisheries Science and Food Production Processes (Qingdao), National Laboratory for Marine Science \\ and Technology, Key Laboratory of Maricultural Organism Disease Control, Ministry of Agriculture, Qingdao \\ Key Laboratory of Mariculture Epidemiology and Biosecurity, Qingdao 266071, China; \\ yaoliang2019@163.com (L.Y.); 13173113773@163.com (W.W.); sangxihang@163.com (S.S.); \\ 15764228381@163.com (J.H.) \\ * $\quad$ Correspondence: lichenghua@nbu.edu.cn (C.L.); zhangq1@ysfri.ac.cn (Q.Z.); Tel.: +86-532-85823062 (Q.Z.); \\ Fax: +86-532-85811514 (Q.Z.)
}

Citation: Wang, C.; Yao, L.; Wang, W.; Sang, S.; Hao, J.; Li, C.; Zhang, Q. First Report on Natural Infection of Nodavirus in an Echinodermata, Sea Cucumber (Apostichopus japonicas). Viruses 2021, 13, 636. https://doi.org/ 10.3390/v13040636

Academic Editor: Karla Helbig

Received: 4 February 2021

Accepted: 24 February 2021

Published: 8 April 2021

Publisher's Note: MDPI stays neutral with regard to jurisdictional claims in published maps and institutional affiliations.

Copyright: (c) 2021 by the authors. Licensee MDPI, Basel, Switzerland. This article is an open access article distributed under the terms and conditions of the Creative Commons Attribution (CC BY) license (https:// creativecommons.org/licenses/by/ $4.0 /)$.

\begin{abstract}
Cross-species transmission of emerging viruses happens occasionally due to epidemiological, biological, and ecological factors, and it has caused more concern recently. Covert mortality nodavirus (CMNV) was revealed to be a unique shrimp virus that could cross species barrier to infect vertebrate fish. In the present study, CMNV reverse transcription-nested PCR (RT-nPCR)-positive samples were identified from farmed sea cucumber (Apostichopus japonicas) in the CMNV host range investigation. The amplicons of RT-nPCR from sea cucumber were sequenced, and its sequences showed $100 \%$ identity with the RNA-dependent RNA polymerase gene of the original CMNV isolate. Histopathological analysis revealed pathologic changes, including karyopyknosis and vacuolation of the epithelial cells, in the sea cucumber intestinal tissue. The extensive positive hybridization signals with CMNV probe were shown in the damaged epithelial cells in the in situ hybridization assay. Meanwhile, transmission electron microscopy analysis revealed CMNV-like virus particles in the intestine epithelium. All the results indicated that the sea cucumber, an Echinodermata, is a new host of CMNV. This study supplied further evidence of the wide host range of CMNV and also reminded us to pay close attention to its potential risk to threaten different aquaculture animal species.
\end{abstract}

Keywords: covert mortality nodavirus (CMNV); natural infection; sea cucumber (Apostichopus japonicas); in situ hybridization; TEM

\section{Introduction}

For most viruses, the virus-receptor interactions determine viral host range and therefore constitute the interspecies barrier of viral infection, eventually leading to the strong host specificity of a virus [1,2]. However, the cross-species transmission of emerging viruses happens occasionally due to a variety of epidemiological, biological, and ecological factors [3-5]. Furthermore, RNA viruses more easily cross species boundaries on account of the lack of exonuclease proofreading activity and easy variation [6], such as coronaviruses [7], the avian influenza virus [8], and the rabies virus [9].

Nodaviridae is composed of two genera, Alphanodavirus and Betanodavirus [10]. Alphanodaviruses were mostly isolated from insects and their host range also appears to be restricted to insects [11], except for Nodamura virus (NoV) and Flock House virus (FHV) [12,13]. NoV was originally isolated from mosquitoes (Culex tritaeniorhynchus) [14]; however, it could also lethally infect mammals, including suckling mice and suckling hamsters $[10,15]$. FHV, another alphanodavirus isolated from Costelytra zealandica (Coleoptera: Scarabaeidae), is capable of replicating in many species of plants, including chenopodium Chenopodium hybridum, barley Hordeum vulgare, and tobacco Nicotiana tabacum [12,16]. Therefore, the 
hosts of NoV and FHV are not only confined to insects, and they also possess the capacity of cross-species transmission as well. However, Betanodavirus mainly infects larvae, juvenile or adult marine fish, and is different from Alphanodavirus [17-19].

Covert mortality nodavirus (CMNV) is an alphanodavirus first isolated from shrimp with viral covert mortality disease (VCMD) in China and later also found in Thailand and Ecuador [20-23]. It can also infect various major farmed shrimp, including Penaeus vannamei, Penaeus chinensis, Marsupenaeus japonicus, and Penaeus monodon, and VCMD outbreaks in shrimp farms represent a significant threat to the shrimp culture industry [21]. Additionally, other crustaceans (including the hyperiid amphipod Parathemisto gaudichaud, amphipod Corophium sinense Zhang, and the ghost crab Ocypode cordimandus) and several fish species (including gobiid fish Mugilogobius abei, Japanese flounder Paralichthys olivaceus, and goldfish Carassius auratus) are also natural hosts of CMNV. And the host range spanning crustaceans and fish illustrates the capacity of CMNV to spread crossing the species barrier [24-26].

Sea cucumber (Holothuians) is a common marine invertebrate [27], and it is the generic term for Holothuroidea, which belongs to the invertebrate Echinodermata. Apostichopus japonicus is the sea cucumber species with the largest social demand, and its aquaculture has become an emerging marine industry [28-30]. In a systematic investigation of CMNV natural hosts and vectors, CMNV reverse transcription-nested PCR (RT-nPCR)-positive sea cucumber individuals were accidentally found in shrimp farming ponds. In this study, we describe here the outcome of the detection of CMNV in sea cucumber by RT-nPCR, in situ hybridization (ISH), histopathology, and transmission electron microscopy (TEM). Our study provides significant novel insights into the new natural host discovery of CMNV.

\section{Materials and Methods}

\subsection{Sample Collection}

In June 2018, we found that the farming P. vannamei collected from polyculture ponds of shrimp and sea cucumber was infected with CMNV. Considering the capacity of CMNV cross-species infection and the needs of further exploration of its host range, four sea cucumber individuals (length $7-8 \mathrm{~cm}$, co-inhabiting with the $P$. vannamei in the same polyculture pond) (Figure 1a,b) were randomly collected for CMNV detection. The collected sea cucumber individuals looked normal, but the body was not compacted enough (somewhat soft) compared with healthy individuals. These sea cucumbers were primarily examined after dissecting the body along the longitudinal axis, and the thinning intestinal tissue (Figure 1c) was selected to be divided into three parts and preserved. One part was preserved in $4 \%$ paraformaldehyde solution in PBS (PFA-PBS) (Sinopharm, Beijing, China) for ISH detection and histopathological analysis. Another part was fixed in $2.5 \%$ glutaraldehyde solution (Solarbio, Beijing, China) for electron microscopic examinations. Residual intestinal tissues were preserved in RNAstore solution (Tiangen, Beijing, China) for molecular biological analysis. 

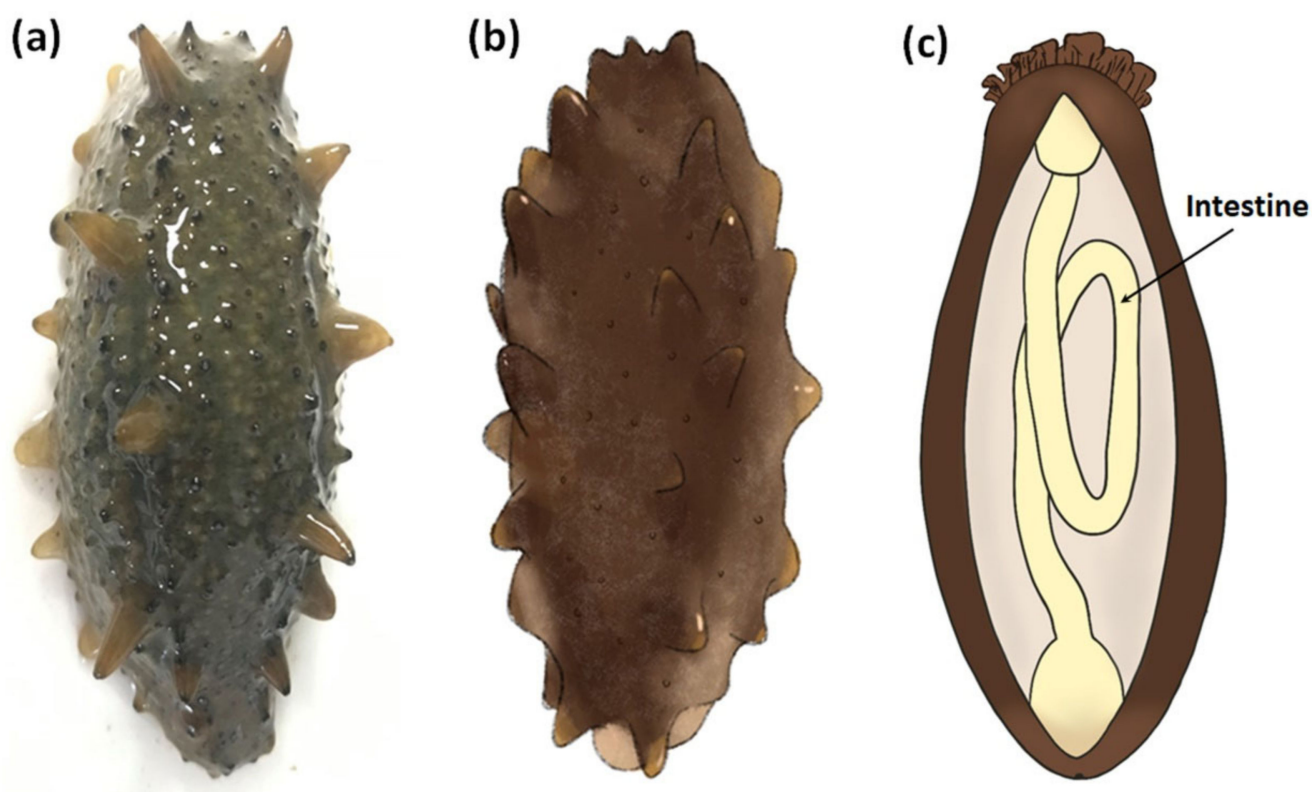

Figure 1. The topography and schematic diagram of the intestine of sea cucumber (Apostichopus japonicas) in this study. (a) Topography of sea cucumber collected from the polyculture ponds infected with covert mortality nodavirus (CMNV). (b) Schematic diagram of sea cucumber. (c) Schematic diagram of the longitudinal section of sea cucumber. Intestinal tissue is pointed by the black arrow.

\subsection{Total RNA Extraction}

The total RNA of intestinal tissues was extracted from four sea cucumber individuals using RNAiso Plus Reagent (Takara, Dalian, China) according to the manufacturer's instructions. The tissues samples were first homogenized in RNAiso Plus, and then trichloromethane was added into the homogenate for protein degeneration. Finally, isopropanol was used to get total RNA from liquid supernatant obtained by centrifugation. The concentration and purity of purified RNA were measured by Nanodrop 2000 (Thermo Scientific, Waltham, MA, USA).

\subsection{Reverse Transcription-Nested PCR (RT-nPCR)}

The total RNA from the intestinal tissue of sea cucumber was used as a template for RTPCR analysis. First, the first-step PCR amplification was conducted by using the template of $1 \mu \mathrm{L}$ total RNA (concentration of the template was 100-200 ng/ $\mu \mathrm{L}$ ) and a PrimeScript One Step RT-PCR Kit (TaKaRa, Dalian, China) with the primer sets of CMNV-F1/R1 (CMNV-F1: 5'-AAATACGGCGATGACG-3', CMNV-R1: 5'-ACGAAGTGCCCA-CAGAC-3') according to the recommended procedures, and the annealing temperature was $52{ }^{\circ} \mathrm{C}$. Using the firststep RT-PCR products as templates, the second-step PCR was carried out using a TaKaRa Ex Taq Kit (TaKaRa, Dalian, China) with the primer sets of CMNV-D-F1/R1 (CMNV-D-F1: 5'-TCGCGTATTCGTGGAT-3', CMNV-D-R1: 5'-TAGGGTCAAAAGGTGTAGT-3'), and the annealing temperature was $52{ }^{\circ} \mathrm{C}$. The expected CMNV target fragments of the first and second rounds of the PCR amplifications were $619 \mathrm{bp}$ and $413 \mathrm{bp}$ amplicons from the CMNV RNA-dependent RNA polymerase (RdRp) gene, respectively. Then, the amplicons were resolved by $2 \%$ agarose gel electrophoresis for $0.5 \mathrm{~h}$.

\subsection{Sequence Alignment and Phylogenetic Tree Analysis}

The amplicons (413 bp) from the second step of the RT-nPCR of sea cucumber were sent for commercial sequencing to Sangon Biological Engineering (Shanghai, China) Co. Ltd. The obtained $413 \mathrm{bp}$ RdRp gene fragment sequences were subjected to multiple sequence alignment by the online software of BLASTn (https:/ / www.ncbi.nlm.nih.gov/, accessed on 4 February 2021). Then, the phylogenetic tree, based on 25 relevant RdRp protein sequences retrieved from the GenBank database (Table 1) and the deduced amino acids sequence of 
the $413 \mathrm{bp}$ gene fragment, was constructed by using the software MEGA 6.0 [31]. The tree was finally optimized through the online tool of iTOL (https://itol.embl.de/, accessed on 4 February 2021).

Table 1. Names and abbreviations for viral species of Nodaviridae.

\begin{tabular}{|c|c|c|}
\hline Virus & Abbreviation & GenBank No. * \\
\hline Covert mortality nodavirus & CMNV & AIL48199.1 \\
\hline Flock House virus & FHV & AEQ39075.1 \\
\hline Gungahlin Chrysomya noda-like virus & GCNV & QIJ70031.1 \\
\hline Newington virus & $\mathrm{NeV}$ & AMO03244.1 \\
\hline $\begin{array}{l}\text { Drosophila melanogaster American nodavirus } \\
\text { (ANV) strain SW-2009a }\end{array}$ & DmANV-SW-2009a & ACU32794.1 \\
\hline Black beetle virus & BBV & YP_053043.1 \\
\hline Wenzhou noda-like virus 6 strain & Wenzhou NLV-6 & APG76600.1 \\
\hline Hubei noda-like virus 21 strain & Hubei NLV-21 & APG76486.1 \\
\hline Hubei noda-like virus 22 strain & Hubei NLV-22 & APG76466.1 \\
\hline Boolarra virus & BoV & NP_689439.1 \\
\hline Nodamura virus & $\mathrm{NoV}$ & NP_077730.1 \\
\hline Shuangao insect virus 11 strain & SIV-11 & YP_009337806.1 \\
\hline Wenzhou noda-like virus 7 strain & Wenzhou NLV-7 & APG76642.1 \\
\hline Beihai noda-like virus 25 strain & Beihai NLV-25 & APG76164.1 \\
\hline Beihai mantis shrimp virus 6 strain & BMSV-6 & YP_009333376.1 \\
\hline Macrobrachium rosenbergii nodavirus & MrNV & AAQ83832.1 \\
\hline Beihai noda-like virus 30 strain & Beihai NLV-30 & APG76125.1 \\
\hline Striped jack nervous necrosis virus & SJNNV & NP_599247 \\
\hline Golden pompano nervous necrosis virus & GPNNV & ACX54065 \\
\hline Redspotted grouper nervous necrosis virus & RGNNV & ACX69744 \\
\hline Dragon grouper nervous necrosis virus & DGNNV & AAU85148 \\
\hline Tiger puffer nervous necrosis virus & TPNNV & YP_00328875 \\
\hline Atlantic cod nodavirus & ACNV & ABR23192 \\
\hline Atlantic halibut nodavirus & AHNV & AAY34458 \\
\hline Barfin flounder nervous necrosis virus & BFNNV & YP_003288756 \\
\hline
\end{tabular}

GenBank No.* indicate the GenBank accession numbers of the amino acid sequence of RNA-dependent RNA polymerase used in this study.

\subsection{In Situ Hybridization (ISH) and Histopathological Analysis}

Fixation, dehydration and paraffin embedding of the tissue samples were conducted following the histological method reported by Bell and Lightner [32]. Two paraffinembedded sections $(3 \mu \mathrm{m})$ were prepared. One of the sections was subjected to CMNV ISH analysis according to the published papers [21,25], and the other section was stained with routine hematoxylin and eosin-phloxine (H\&E) according to previously described procedures [33]. The ISH sections were counterstained using the Nuclear Fast Red solution (Solarbio, Beijing, China) [34]. Finally, the sections of ISH detection and H\&E staining were analyzed under the Nikon Eclipse E80i microscope (Nikon Co., Tokyo, Japan), and the image acquisition was accomplished through the slide scanning system of Pannoramic MIDI (3DHISTECH Ltd., Budapest, Hungary).

\subsection{Transmission Electron Microscopy Analysis}

To detect the presence of CMNV particles in sea cucumber, the intestinal tissues (approximately $1 \mathrm{~mm}^{3}$ ) were first preserved in $2.5 \%$ glutaraldehyde for $24 \mathrm{~h}$ at $4{ }^{\circ} \mathrm{C}$, and then further fixed in $1 \%$ osmium tetroxide for $2 \mathrm{~h}$. Finally, the tissues were embedded in plastic resin $[35,36]$. An ultramicrotome (Leica EM UC7) was used to prepare ultrathin sections $(50 \mathrm{~nm})$ of a resin block, and the obtained sections were stained with uranyl acetate and lead citrate [37,38]. Eventually, all the sections were examined using a JEOL JEM-1200 electron microscope (equipped with a field emission gun). 


\section{Results}

\subsection{Detection of CMNV in Sea Cucumber by RT-nPCR}

Two out of the four RNA samples from the sea cucumbers produced the expected amplicons (413 bp) in the RT-nPCR assay (Figure 2a). In addition, the $413 \mathrm{bp}$ amplicons of the second-step PCR were then sequenced to confirm the exact sequence information of RdRp-targeted fragments.
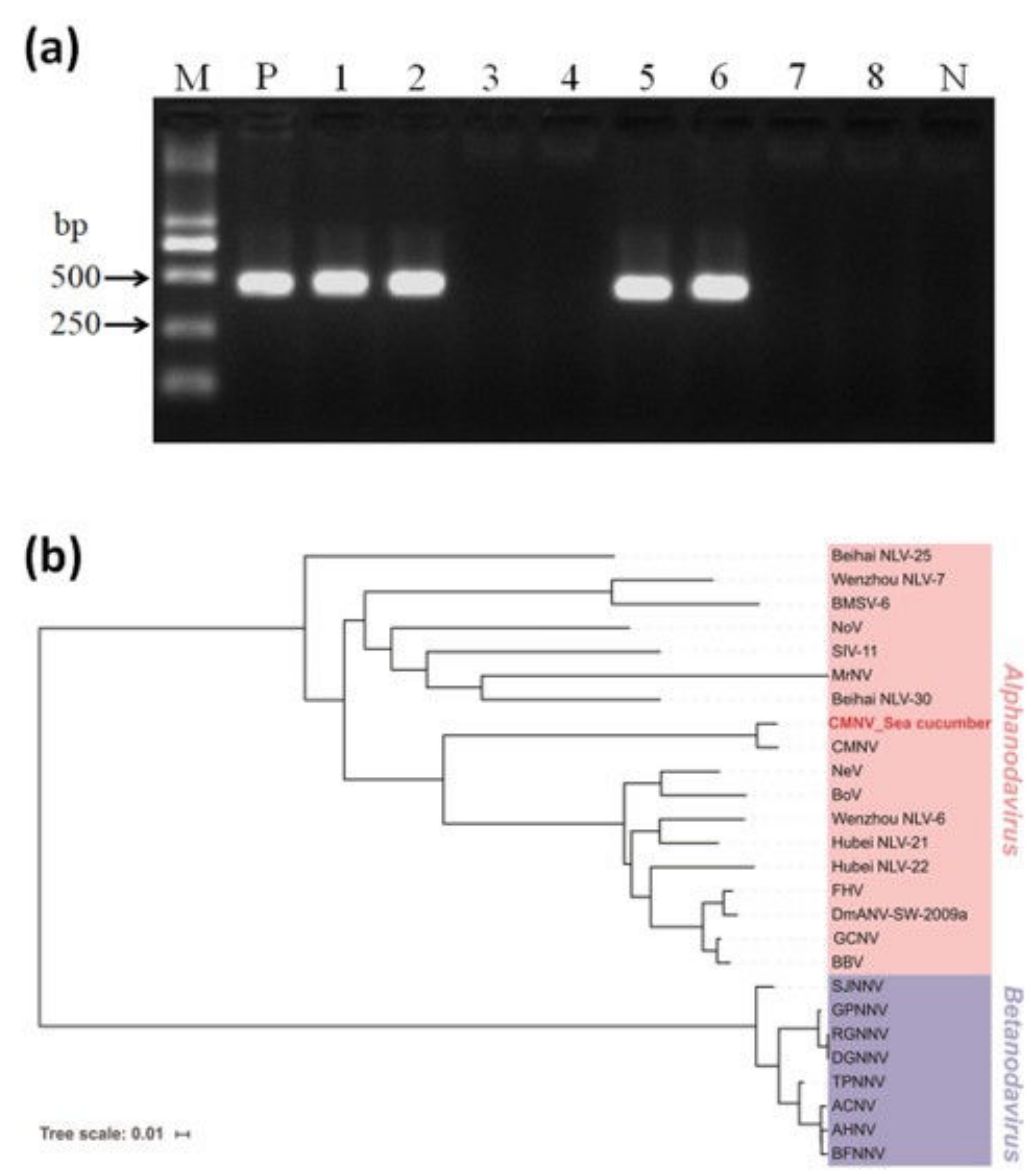

Figure 2. Electrophoretogram of amplicons from the CMNV RT-nPCR assay and phylogenetic analysis. (a) Electrophoretogram of amplicons from the second-step PCR of the CMNV RT-nPCR assay. M: DL2000 molecular weight marker. Lanes 1-8: the PCR products of four RNA samples from sea cucumbers' intestines (each sample was done with two replicates; samples 1, 2, 3, and 4 were shown in lanes 1 and 2, 3 and 4, 5 and 6, 7 and 8, respectively). P: positive control; $N$ : negative control. (b) Analysis of the phylogenetic tree based on the deduced amino acid sequences of the RdRp gene from the CMNV-positive sea cucumber sample and other nodaviruses (abbreviations of other viruses shown in Table 1). The CMNV isolate of the sea cucumber sampled from farming ponds is highlighted in red. Viral species of Alphanodavirus genus and Betanodavirus genus are shown in pink and lavender background, respectively. The phylogeny tree was derived using the neighbor-joining method by the MEGA 6.0 program. The scale bar is 0.01 .

\subsection{Phylogenetic Analyses}

The result of multiple sequence alignment based on the $413 \mathrm{bp}$ amplicons (413 bp, GenBank No. MW678771) from the second-step PCR showed that the CMNV sequences of sea cucumber shared $100 \%$ identity with the known CMNV RdRp gene (GenBank no. KM112247). Phylogenetic analysis revealed that the deduced amino acid sequences of CMNV RdRp from sea cucumber samples were clustered closely into the embranchment of the primordial CMNV isolate (Figure 2b). Additionally, the phylogenetic tree showed that the CMNV RdRp fragment sequences from sea cucumber were clustered into Alphano- 
davirus, and that members from Betanodavirus were clustered into the other independent branch (Table 1).

\subsection{Detection of CMNV in Sea Cucumber by ISH and Histopathological Analysis}

Purple positive hybridization signals of $\mathrm{CMNV}$ probe were widely present in the intestine of CMNV RT-nPCR-positive sea cucumber (Figure 3c), and especially more pronounced in intestinal epithelial cells (Figure 3d). Meanwhile, histological examination revealed obvious histopathological lesions in the same sites, such as villi decreasing, villus epithelium cells becoming uncompact and acidophilic (comparing with the normal villus epithelium cells), karyopyknosis (red arrows) and extensive vacuolation (yellow arrows) in the intestinal epithelial cells (Figure 3a,b). The result of ISH and histopathological analysis of the intestine of sea cucumber of negative control is shown in Figure 4a-d. No obvious histopathological changes and CMNV-positive hybridization signals were observed in the intestinal tissue (Figure 4c,d).
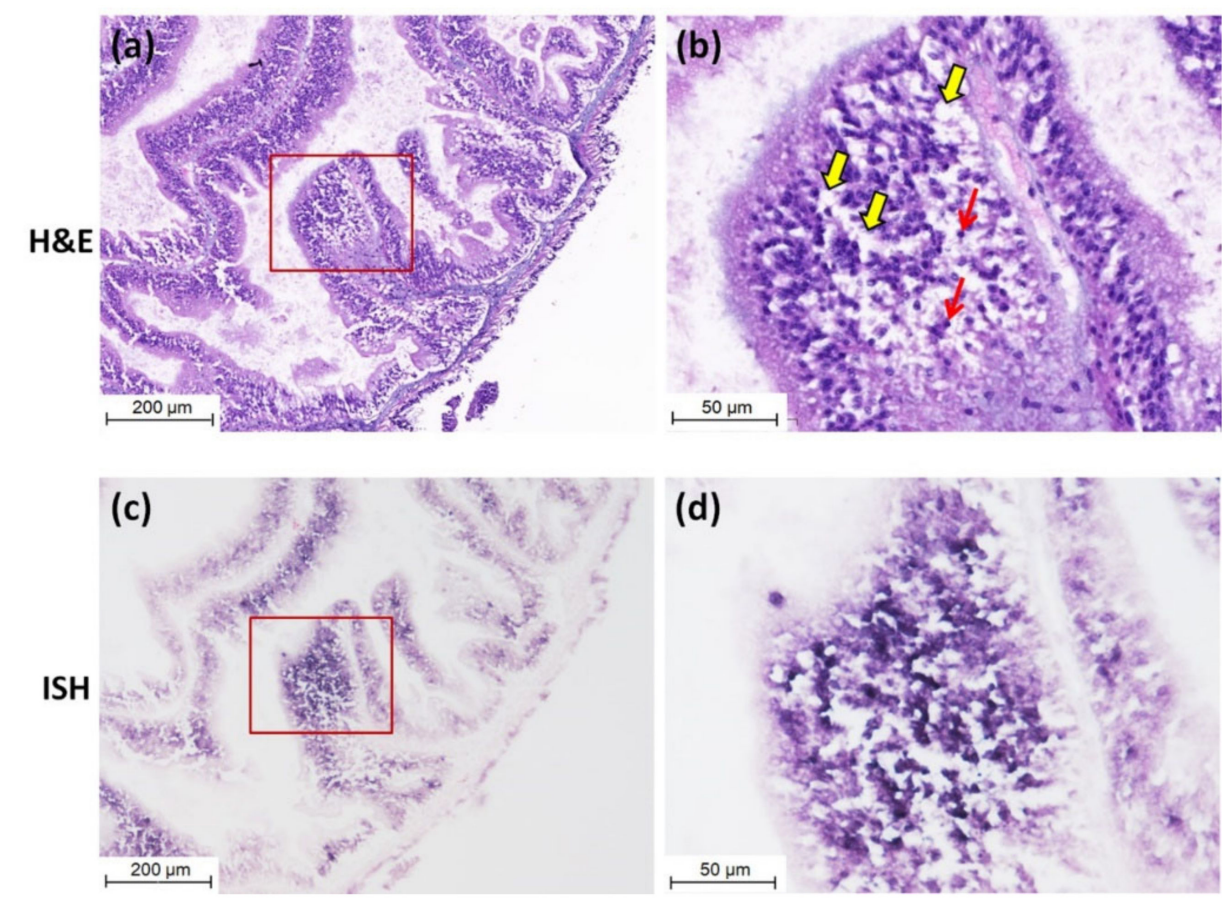

Figure 3. Micrographs of hematoxylin and eosin-phloxine (H\&E) staining and in situ hybridization (ISH) of the intestine of sea cucumber naturally infected with CMNV. (a) Micrographs of H\&E staining of the intestine. (b) Magnified micrographs from the red-framed areas of (a). Karyopyknosis (red arrows) and extensive vacuolation (yellow arrows) were observed in the intestinal epithelial cells. (c) Micrographs of ISH of the intestine. (d) Magnified micrographs from the red-framed areas of (c). Intense $\mathrm{CMNV}$ positive hybridization signals (colored deep-purple) were detected in the intestinal epithelial cells. Scale bars: (a,c) $200 \mu \mathrm{m},(\mathbf{b}, \mathbf{d}) 50 \mu \mathrm{m}$. 

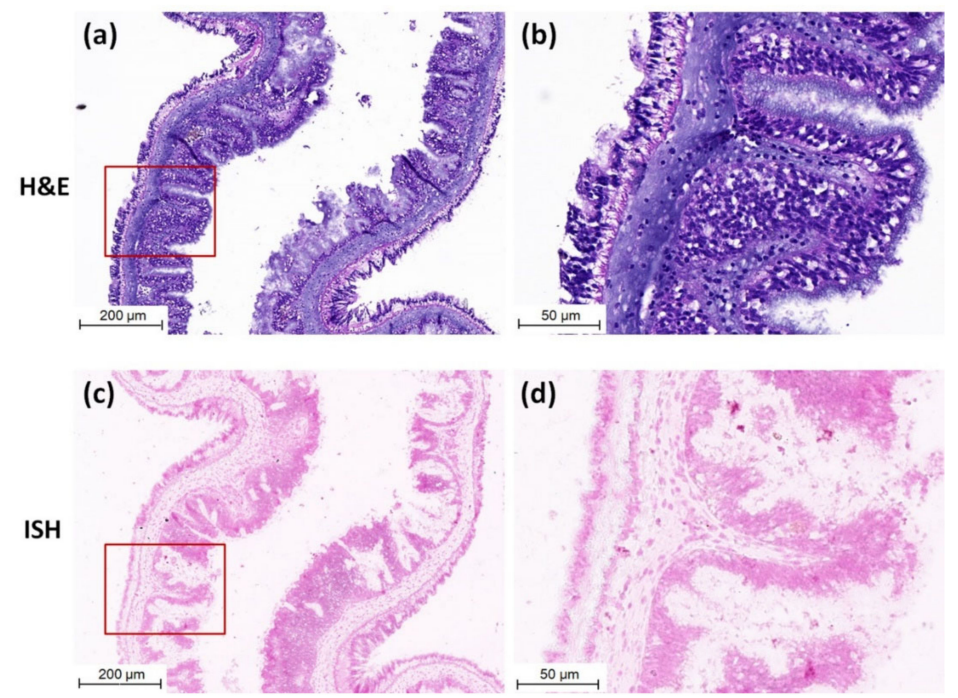

Figure 4. Micrographs of H\&E staining and ISH of the intestinal tissue of sea cucumber of negative control. (a) Micrographs of H\&E staining of negative control intestinal tissue. (b) Magnified micrographs from the red-framed areas of (a). No obvious histopathological change was observed in the intestinal tissue. (c) Micrographs of ISH of negative control intestinal tissue. (d) Magnified micrographs from the red-framed areas of (c). No CMNV positive hybridization signal was detected in the intestinal tissue. Scale bars: $(\mathbf{a}, \mathbf{c}) 200 \mu \mathrm{m},(\mathbf{b}, \mathbf{d}) 50 \mu \mathrm{m}$.

\subsection{Detection of CMNV in Sea Cucumber by TEM Analysis}

TEM analysis was used to further confirm the CMNV infection in the sea cucumber. TEM micrographs of the ultrathin sections of the intestinal tissue of sea cucumber revealed the presence of massive CMNV-like virus particles of about 28-32 nm in the intestinal villus epithelium cells (Figure 5a-d).
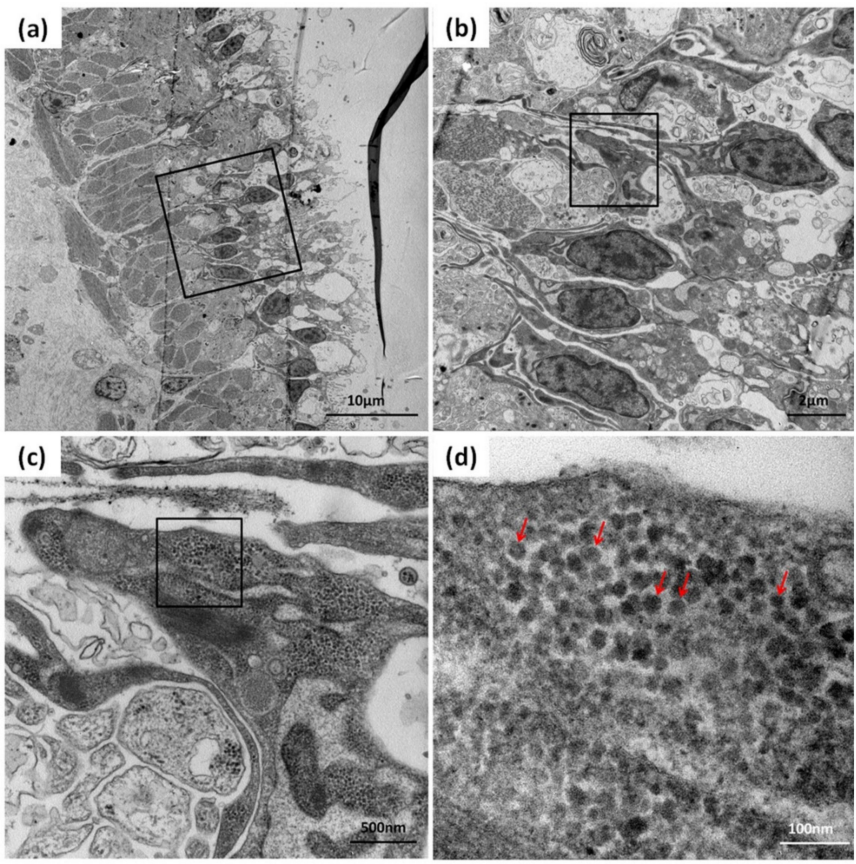

Figure 5. TEM micrographs of an ultrathin section of the intestinal epithelial cells of sea cucumber from the farm infected with CMNV. (b-d) show magnified micrographs in the black-framed areas of $(\mathbf{a}-\mathbf{c})$, respectively. Note the scattering of CMNV-like virus particles (red arrows) at the intestinal villus epithelium cells. Scale bars: (a) $10 \mu \mathrm{m}$, (b) $2 \mu \mathrm{m}$, (c) $500 \mathrm{~nm}$, (d) $100 \mathrm{~nm}$. 


\section{Discussion}

Recently, the phenomenon of cross-species transmission of a few viruses has negatively affected areas such as human life, animal husbandry, and aquaculture and, meanwhile, also piqued the concern of scholars [25,39,40]. Notably, CMNV, an RNA virus isolated from invertebrate shrimp, can cross the host barrier to infect vertebrate fish, including the marine fishes gobiid fish Mugilogobius abei and Japanese flounder Paralichthys olivaceus [24,25], as well as the freshwater fish goldfish Carassius auratus [25]. CMNV infection in fish reminds that we should pay attention to the potential ability of CMNV to cross more species barriers. Hence, it makes sense to strengthen the investigation of the host range of CMNV. In this study, we proved that sea cucumber is a new natural host of CMNV-something that, to the best of our knowledge, has not been reported before in echinoderms.

CMNV-positive individuals were found in the farming sea cucumber by RT-nPCR. Thus, a further investigation was performed to confirm the infection of CMNV in sea cucumber. The histopathological analysis revealed that obvious pathological lesions, including karyopyknosis and vacuolation of the epithelial cells, occur in the sea cucumber intestinal tissue, and these lesions are similar to the intestinal lesions of gobiid fish Mugilogobius abei infected with CMNV [24]. Consistently, extensive positive hybridization signals of the CMNV probe were also revealed in the damaged epithelial cells in the ISH assay. Meanwhile, the presence of CMNV-like particles in lesion sites of the intestine was also confirmed by TEM analysis. In addition, it was found that the amplicons of RT-nPCR from sea cucumber were highly identical to the CMNV original RdRp gene. Therefore, the above results demonstrated that the sea cucumber could be infected by CMNV and turned into a new natural host of CMNV. In addition, sea cucumber has been continually attacked by disease in recent years [41-43], and whether CMNV is one of the important pathogens should be of concern.

During the past decade, the rapid and disorderly expansion of sea cucumber aquaculture was companied by various diseases that caused high mortality of sea cucumbers, resulting in grievous economic losses to the culture industry of sea cucumber $[44,45]$. Frequent outbreaks of disease has obviously hindered the sustainable development of sea cucumber culture industry. The studies on infectious agents of sea cucumber have been frequently reported in the past 10 years [46]. For many of these disease events, most research has focused on bacterial pathogens such as Vibrio harveyi [47], Vibrio splendidus [48], and Lactococcus garviaeae [49], while studies on viral pathogens have been relatively rare. Some scholars successfully isolated DNA viruses from diseased sea cucumbers, reproduced the disease symptoms, and speculated that the virus might be one of the pathogens causing diseases $[46,50,51]$. However, to date, no virus has been definitely identified and named. The discovery of CMNV in sea cucumber might provide more possibility and theoretical basis for the research of viral pathogens in diseased sea cucumber.

It is known that sea cucumber, a scavenger, is the pivotal component of the marine environment [52], playing an important role in the recycling of marine ecosystems [53]. In addition, sea cucumber is considered an important aquaculture species in East Asian countries because it has high nutritional value and is rich in multiple nutrients and biologically active substances [54-57]. Because of increased market demand, sea cucumber culture has become one of the pillar industries of China's aquaculture industry $[58,59]$. The natural infection of CMNV in sea cucumber reveals the potential risk of CMNV to the maintaining of sea cucumber natural resources in marine ecosystems, as well as to the aquaculture of the increasingly important species.

\section{Conclusions}

Overall, the results of this study demonstrated that CMNV is a broad host range virus that deserves close attention to its potential risk to infect more aquaculture animal species. Considering the key ecological function of sea cucumber in the marine environment and the high economic value of this aquatic species, the potential negative impact of the spread and prevalence of CMNV in sea cucumber on the marine ecosystem and social economy 
should be of concern. The present study contributes to further investigation of the viral pathogen of diseased sea cucumber.

Author Contributions: C.W., C.L. and Q.Z. designed this experiment. W.W. drew the diagram of sea cucumber. C.W. completed the experiments and organized the data. Q.Z., L.Y., S.S. and J.H. collected the samples used in this study. Q.Z. conducted the transmission electron microscopy analysis. C.W. wrote the manuscript, and C.L. and Q.Z. revised it. All authors have read and agreed to the published version of the manuscript.

Funding: This research was funded by the National R\&D Program of China (2017YFC1404503), National Natural Science Foundation of China (32073016), Central Public-interest Scientific Institution Basal Research Fund, CAFS (No. 2020TD39), Project of Species Conservation from the MARA-Marine Fisheries Resources Collection and Preservation, and Central Public-interest Scientific Institution Basal Research Fund, YSFRI, CAFS (No. 20603022020005).

Institutional Review Board Statement: Not applicable.

Informed Consent Statement: Not applicable.

Data Availability Statement: Not applicable.

Conflicts of Interest: The authors declare no conflict of interest.

\section{References}

1. Schneider-Schaulies, J. Cellular receptors for viruses: Links to tropism and pathogenesis. J. Gen. Virol. 2000, 81, 1413-1429. [CrossRef] [PubMed]

2. Kuiken, T.; Holmes, E.C.; McCauley, J.; Rimmelzwaan, G.F.; Williams, C.S.; Grenfell, B.T. Host Species Barriers to Influenza Virus Infections. Science 2006, 312, 394-397. [CrossRef] [PubMed]

3. Leopardi, S.; Holmes, E.C.; Gastaldelli, M.; Tassoni, L.; Priori, P.; Scaravelli, D.; Zamperin, G.; De Benedictis, P. Interplay between co-divergence and cross-species transmission in the evolutionary history of bat coronaviruses. Infect. Genet. Evol. 2018, 58, 279-289. [CrossRef] [PubMed]

4. Parrish, C.R.; Holmes, E.C.; Morens, D.M.; Park, E.-C.; Burke, D.S.; Calisher, C.H.; Laughlin, C.A.; Saif, L.J.; Daszak, P. CrossSpecies Virus Transmission and the Emergence of New Epidemic Diseases. Microbiol. Mol. Biol. Rev. 2008, 72, 457-470. [CrossRef]

5. Johnson, C.K.; Hitchens, P.L.; Evans, T.S.; Goldstein, T.; Thomas, K.; Clements, A.; Joly, D.O.; Wolfe, N.D.; Daszak, P.; Karesh, W.B.; et al. Spillover and pandemic properties of zoonotic viruses with high host plasticity. Sci. Rep. 2015, 5, 14830. [CrossRef]

6. Holmes, E.C. The Evolution and Emergence of RNA Viruses; Oxford University Press: Oxford, UK, 2009.

7. Wang, L.-F.; Anderson, D.E. Viruses in bats and potential spillover to animals and humans. Curr. Opin. Virol. $2019,34,79-89$. [CrossRef] [PubMed]

8. Bourret, V.; Lyall, J.; Frost, S.D.W.; Teillaud, A.; Smith, C.A.; LeClaire, S.; Fu, J.; Gandon, S.; Guérin, J.-L.; Tiley, L.S. Adaptation of avian influenza virus to a swine host. Virus Evol. 2017, 3, vex007. [CrossRef] [PubMed]

9. Ding, N.-Z.; Xu, D.-S.; Sun, Y.-Y.; He, H.-B.; He, C.-Q. A permanent host shift of rabies virus from Chiroptera to Carnivora associated with recombination. Sci. Rep. 2017, 7, 1-9. [CrossRef]

10. Owens, F.; Di Serio, F.; Li, S.; Pallás, V.; Randles, J.; Sano, V. Virus Taxonomy: Ninth Report of the International Committee on Taxonomy of Viruses; Academic Press: San Diego, CA, USA, 2012; pp. 1221-1234.

11. Johnson, K.L.; Price, B.D.; Ball, L.A. Recovery of Infectivity from cDNA Clones of Nodamura Virus and Identification of Small Nonstructural Proteins. Virology 2003, 305, 436-451. [CrossRef]

12. Selling, B.H.; Allison, R.F.; Kaesberg, P. Genomic RNA of an insect virus directs synthesis of infectious virions in plants. Proc. Natl. Acad. Sci. USA 1990, 87, 434-438. [CrossRef]

13. Hurd, H. Review of "Insect Pathogens: Molecular Approaches and Techniques" by S. P. Stock, J. Vandenberg, I. Glazer and N. Boemare. Parasites Vectors 2009, 2, 28. [CrossRef]

14. Scherer, W.F.; Verna, J.E.; Richter, G.W. Nodamura Virus, an Ether- and Chloroform-Resistant Arbovirus from Japan. Am. J. Trop. Med. Hyg. 1968, 17, 120-128. [CrossRef]

15. Ball, L.A.; Johnson, K.L. Reverse Genetics of Nodaviruses. Adv. Appl. Microbiol. 1999, 53, 229-244. [CrossRef]

16. Scotti, P.D.; Dearing, S.; Mossop, D.W. Flock house virus: A Nodavirus isolated fromCostelytra zealandica (White) (Coleoptera: Scarabaeida). Arch. Virol. 1983, 75, 181-189. [CrossRef]

17. Iwamoto, T.; Okinaka, Y.; Mise, K.; Mori, K.-I.; Arimoto, M.; Okuno, T.; Nakai, T. Identification of Host-Specificity Determinants in Betanodaviruses by Using Reassortants between Striped Jack Nervous Necrosis Virus and Sevenband Grouper Nervous Necrosis Virus. J. Virol. 2004, 78, 1256-1262. [CrossRef] [PubMed] 
18. Furusawa, R.; Okinaka, Y.; Uematsu, K.; Nakai, T. Screening of freshwater fish species for their susceptibility to a betanodavirus. Dis. Aquat. Org. 2007, 77, 119-125. [CrossRef] [PubMed]

19. Souto, S.; Lopez-Jimena, B.; Alonso, M.; García-Rosado, E.; Bandín, I. Experimental susceptibility of European sea bass and Senegalese sole to different betanodavirus isolates. Veter. Microbiol. 2015, 177, 53-61. [CrossRef]

20. Zhang, Q.; Liu, Q.; Liu, S.; Yang, H.; Liu, S.; Zhu, L.; Yang, B.; Jin, J.; Ding, L.; Wang, X.; et al. A new nodavirus is associated with covert mortality disease of shrimp. J. Gen. Virol. 2014, 95, 2700-2709. [CrossRef]

21. Zhang, Q.; Xu, T.; Wan, X.; Liu, S.; Wang, X.; Li, X.; Dong, X.; Yang, B.; Huang, J. Prevalence and distribution of covert mortality nodavirus (CMNV) in cultured crustacean. Virus Res. 2017, 233, 113-119. [CrossRef]

22. Thitamadee, S.; Prachumwat, A.; Srisala, J.; Jaroenlak, P.; Salachan, P.V.; Sritunyalucksana, K.; Flegel, T.W.; Itsathitphaisarn, O. Review of current disease threats for cultivated penaeid shrimp in Asia. Aquaculture 2016, 452, 69-87. [CrossRef]

23. Pooljun, C.; Direkbusarakom, S.; Chotipuntu, P.; Hirono, I.; Wuthisuthimethavee, S. Development of a TaqMan real-time RT-PCR assay for detection of covert mortality nodavirus (CMNV) in penaeid shrimp. Aquaculture 2016, 464, 445-450. [CrossRef]

24. Liu, S.; Wang, X.; Xu, T.; Li, X.; Du, L.; Zhang, Q. Vectors and reservoir hosts of covert mortality nodavirus (CMNV) in shrimp ponds. J. Invertebr. Pathol. 2018, 154, 29-36. [CrossRef] [PubMed]

25. Wang, C.; Wang, X.H.; Liu, S.; Sang, S.W.; Zhang, Q.L. Preliminary study on the natural infection of Carassius auratus with covert mortality nodavirus (CMNV). Prog. Fish. Sci. 2019, 40, 25-32.

26. Zhang, Q.L.; Liu, S.; Li, J.; Xu, T.T.; Wang, X.H.; Fu, G.M.; Li, X.P.; Sang, S.W.; Bian, X.D.; Hao, J.W. Evidence for Cross-Species Transmission of Covert Mortality Nodavirus to New Host of Mugilogobius abei. Front. Microbiol. 2018, 9, 1447. [CrossRef]

27. Byrne, M.; Rowe, F.; Uthicke, S. Molecular taxonomy, phylogeny and evolution in the family Stichopodidae (Aspidochirotida: Holothuroidea) based on COI and 16S mitochondrial DNA. Mol. Phylogenetics Evol. 2010, 56, 1068-1081. [CrossRef]

28. Li, J.Y. The Immunological Characters and Pathogenic Study of Cultured Apostichopus japonicus. Ph.D. Thesis, Ocean University of China, Qingdao, China, 2007.

29. McElroy, S. Beche-de-mer species of commercial value-An update. SPC Beche-De-Mer Info. Bull. 1990, 2, 2-7.

30. Han, H.; Yi, Y.H.; Li, L.; Liu, B.S.; Pan, M.X.; Yan, B.; Wang, X.H. Triterpene glycosides from sea cucumber Holothuria leucospilota. Chiu J. Nat. Med. 2009, 7, 346-350. [CrossRef]

31. Tamura, K.; Stecher, G.; Peterson, D.; Filipski, A.; Kumar, S. MEGA6: Molecular Evolutionary Genetics Analysis Version 6.0. Mol. Biol. Evol. 2013, 30, 2725-2729. [CrossRef]

32. Bell, T.A.; Lightner, D.V. A Handbook of Normal Penaeid Shrimp Histology; World Aquaculture Society: Baton Rouge, LA, USA, 1988.

33. Lightner, D.V. A Handbook of Shrimp Pathology and Diagnostic Procedures for Diseases of Cultured Penaeid Shrimp; World Aquaculture Society: Baton Rouge, LA, USA, 1996.

34. Nuovo, G.J.; Plaia, T.W.; Belinsky, S.A.; Baylin, S.B.; Herman, J.G. In situ detection of the hypermethylation-induced inactivation of the p16 gene as an early event in oncogenesis. Proc. Natl. Acad. Sci. USA 1999, 96, 12754-12759. [CrossRef] [PubMed]

35. Fortunato, T.M.; Beltrami, C.; Emanueli, C.; De Bank, P.A.; Pula, G. Platelet lysate gel and endothelial progenitors stimulate microvascular network formation in vitro: Tissue engineering implications. Sci. Rep. 2016, 6, 25326. [CrossRef] [PubMed]

36. Zechmann, B.; Zellnig, G. Rapid diagnosis of plant virus diseases by transmission electron microscopy. J. Virol. Methods 2009, 162, 163-169. [CrossRef]

37. Graham, L.; Orenstein, J.M. Processing tissue and cells for transmission electron microscopy in diagnostic pathology and research. Nat. Protoc. 2007, 2, 2439-2450. [CrossRef]

38. Panphut, W.; Senapin, S.; Sriurairatana, S.; Withyachumnarnkul, B.; Flegel, T.W. A novel integrase-containing element may interact with Laem-Singh virus (LSNV) to cause slow growth in giant tiger shrimp. BMC Veter. Res. 2011, 7, 18. [CrossRef] [PubMed]

39. Pauly, M.; Snoeck, C.J.; Phoutana, V.; Keosengthong, A.; Sausy, A.; Khenkha, L.; Nouanthong, P.; Samountry, B.; Jutavijittum, P.; Vilivong, K.; et al. Cross-species transmission of poultry pathogens in backyard farms: Ducks as carriers of chicken viruses. Avian Pathol. 2019, 48, 503-511. [CrossRef] [PubMed]

40. Li, X.; Zai, J.; Zhao, Q.; Nie, Q.; Li, Y.; Foley, B.T.; Chaillon, A. Evolutionary history, potential intermediate animal host, and cross-species analyses of SARS-CoV-2. J. Med Virol. 2020, 92, 602-611. [CrossRef] [PubMed]

41. Zhao, Y.; Guo, M.; Lv, Z.; Zhang, W.; Shao, Y.; Zhao, X.; Li, C. Fas-associated death domain (FADD) in sea cucumber (Apostichopus japonicus): Molecular cloning, characterization and pro-apoptotic function analysis. Dev. Comp. Immunol. 2020, 108, 103673. [CrossRef] [PubMed]

42. Li, H.; Qiao, G.; Gu, J.; Zhou, W.; Li, Q.; Woo, S.; Xu, D.; Park, S. Phenotypic and genetic characterization of bacteria isolated from diseased cultured sea cucumber Apostichopus japonicus in northeastern China. Dis. Aquat. Org. 2010, 91, 223-235. [CrossRef]

43. Shao, Y.; Li, C.; Ou, C.; Zhang, P.; Lu, Y.; Su, X.; Li, Y.; Li, T. Divergent Metabolic Responses of Apostichopus japonicus Suffered from Skin Ulceration Syndrome and Pathogen Challenge. J. Agric. Food Chem. 2013, 61, 10766-10771. [CrossRef] [PubMed]

44. Yang, G.; Tian, X.; Dong, S.; Peng, M.; Wang, D.; Zhang, K. Effects of dietary rhubarb, Bacillus cereus, yeast polysaccharide, and florfenicol supplementation on growth, intestinal morphology, and immune responses of sea cucumber (Apostichopus japonicus). Aquac. Int. 2015, 24, 675-690. [CrossRef]

45. Song, Z.R. Pathology of Aquatic Animal; Xiamen University Press: Xiamen, China, 2009.

46. Deng, H.; Zhou, Z.-C.; Wang, N.-B.; Liu, C. The syndrome of sea cucumber (Apostichopus japonicus) infected by virus and bacteria. Virol. Sin. 2008, 23, 63-67. [CrossRef] 
47. Morgan, A. The effect of food availability on early growth, development and survival of the sea cucumber Holothuria scabra (Echinodermata: Holothuroidea). SPC Beche-De-Mer Inf. Bull. 2001, 14, 6-12.

48. Zhang, C.Y.; Wang, Y.G.; Rong, X.J. Isolation and identification of causative pathogen for skin ulcerative syndrome in Apostichopus japonicus. J. Fish. China 2006, 30, 118-123.

49. Zhang, Z.; Xing, R.; Lv, Z.; Shao, Y.; Zhang, W.; Zhao, X.; Li, C. Analysis of gut microbiota revealed Lactococcus garviaeae could be an indicative of skin ulceration syndrome in farmed sea cucumber Apostichopus japonicus. Fish Shellfish Immunol. 2018, 80, 148-154. [CrossRef] [PubMed]

50. Wang, P.; Chang, Y.; Yu, J.; Li, C.; Xu, G. Acute peristome edema disease in juvenile and adult sea cucumbers Apostichopus japonicus (Selenka) reared in North China. J. Invertebr. Pathol. 2007, 96, 11-17. [CrossRef] [PubMed]

51. Wang, G.X.; Yuan, J.L.; Zhao, Y.K.; Yuan, M. Isolation, identification and drug sensitivity of the pathogens of the skin ulceration disease in Apostichopus japonicus. J. Northwest A F Univ. (Nat. Sci. Ed.) 2007, 35, 87-90.

52. Nerva, L.; Forgia, M.; Ciuffo, M.; Chitarra, W.; Chiapello, M.; Vallino, M.; Varese, G.; Turina, M. The mycovirome of a fungal collection from the sea cucumber Holothuria polii. Virus Res. 2019, 273, 197737. [CrossRef]

53. MacTavish, T.; Stenton-Dozey, J.; Vopel, K.; Savage, C. Deposit-Feeding Sea Cucumbers Enhance Mineralization and Nutrient Cycling in Organically-Enriched Coastal Sediments. PLoS ONE 2012, 7, e50031. [CrossRef]

54. Li, L.; Li, Q. Effects of stocking density, temperature, and salinity on larval survival and growth of the red race of the sea cucumber Apostichopus japonicus (Selenka). Aquac. Int. 2009, 18, 447-460. [CrossRef]

55. Liu, X.F.; Xue, C.H.; Wang, Y.M.; Li, H.Y. Comparative analysis of nutritive composition in body wall and internal organs of sea cucumber (Apostichopus japonicus)at Rushan. J. Fish. China 2011, 35, 587-593.

56. Yang, H.; Hamel, J.F.; Mercier, A. The Sea Cucumber Apostichopus japonicus: History, Biology and Aquaculture; Academic Press: Cambridge, MA, USA, 2015.

57. Purcell, S.W.; Lovatelli, A.; Vasconcellos, M.; Ye, Y. Managing Sea Cucumber Fisheries with An Ecosystem Approach; FAO Fisheries and Aquaculture Technical Paper 520; FAO: Rome, Italy; p. 157.

58. Gu, M.; Ma, H.; Mai, K.; Zhang, W.; Ai, Q.; Wang, X.; Bai, N. Immune response of sea cucumber Apostichopus japonicus coelomocytes to several immunostimulants in vitro. Aquaculture 2010, 306, 49-56. [CrossRef]

59. Liu, H.; Zheng, F.; Sun, X.; Hong, X.; Dong, S.; Wang, B.; Tang, X.; Wang, Y. Identification of the pathogens associated with skin ulceration and peristome tumescence in cultured sea cucumbers Apostichopus japonicus (Selenka). J. Invertebr. Pathol. 2010, 105, 236-242. [CrossRef] [PubMed] 